\title{
Different approaches in diagnosis, follow-up and treatment of acute biliary pancreatitis: Results of attitude survey
}

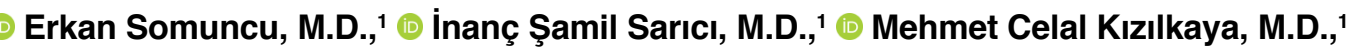

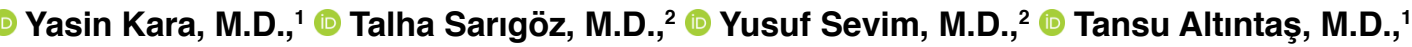

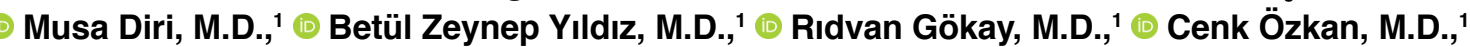

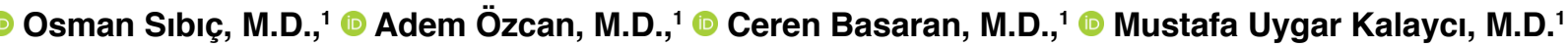

\begin{abstract}
1Department of General Surgery, University of Health Sciences, Kanuni Sultan Suleyman Training and Research Hospital, İstanbul-Turkey ${ }^{2}$ Department of General Surgery, University of Health Sciences, Kayseri City Hospital, Kayseri-Turkey
\end{abstract}

\begin{abstract}
BACKGROUND: Acute biliary pancreatitis is one of the most frequently encountered diseases among general surgeons in emergency surgical diseases. Differences in diagnosis and treatment management of these patients, varying from physician to physician, are common in clinical practice. We aimed to present these differences and discuss the results in the light of current guidelines in the literature.

METHODS: In this study, 2 I questions were prepared regarding the physicians' approach in the diagnosis, follow-up and treatment of acute biliary pancreatitis (Appendix). The questionnaires were completed by face to face interviews with 94 general surgery specialists at the 20th National Surgery Congress.

RESULTS: In this study, 38 (40\%) of the physicians who answered the questionnaire were working in the Training and Research Hospital, $27(29 \%)$ in the State Hospital, $19(20 \%)$ in the University Hospital and nine in private health care was working in the establishment. $85 \%$ of the physicians were general surgery specialists with 10 years of experience. $53 \%(50)$ of the surgeons reported that they had less than five cases of acute biliary pancreatitis each month, and 35\% (34) stated that they wanted amylase value daily for follow-up. Ultrasonography and computed tomography were the most commonly used imaging modalities and I5\% of the respondents indicated that each patient underwent magnetic resonance cholangiopancreatography. $45 \%$ of surgeons stated that antibiotics were started at the time of diagnosis of pancreatitis. The percentage of surgeons who did not undergo cholecystectomy early in patients with mild to moderate pancreatitis was $60 \%$. The reason for not preferring surgery in the early period was the most frequent operation difficulty with $40 \%$ and not supporting the operation in the early period.
\end{abstract}

CONCLUSION: According to the attitude survey results, there are differences between general surgery specialists in the diagnosis, follow-up and treatment of acute biliary pancreatitis.

Keywords: Acute biliary pancreatitis; an attitude survey of pancreatitis; management of pancreatitis.

\section{INTRODUCTION}

Acute pancreatitis is a common gastrointestinal disease with high morbidity and mortality rates worldwide. ${ }^{[1,2]}$ Many guidelines have been published by different gastroenterology and surgical communities for the management of acute pancreatitis. In 2010, nearly 30 guidelines for the management of acute pancreatitis were analyzed in a study. The quality score of the American College of Gastroenterology (ACG) guidelines (revised in 2013) is the highest among the American-based guidelines. ${ }^{[2]}$ In addition, there are three other approved international guidelines-British Gastroenterology Association guidelines, the Japan Association of Abdominal Emergency Medicine guidelines, and the International Association of Pancreatology (AP) guidelines. ${ }^{[3-5]}$ Some institutions also have their own guidelines. ${ }^{[6]}$

\footnotetext{
Cite this article as: Somuncu E, Sarıcı İ̧̧, Kızılkaya MC, Kara Y, Sarı̈öz T, Sevim Y, et al. Different approaches in diagnosis, follow-up and treatment of acute biliary pancreatitis: Results of attitude survey. Ulus Travma Acil Cerrahi Derg 2020;26:932-936.

Address for correspondence: Erkan Somuncu, M.D.

SBÜ İstanbul Kanuni Sultan Süleyman Eğitim ve Araştırma Hastanesi, Genel Cerrahi Anabilim Dalı, İstanbul, Turkey

Tel: +90 212 - 4041500 E-mail: dr.somuncu@gmail.com

Ulus Travma Acil Cerrahi Derg 2020;26(6):932-936 DOI: 10.14744/tjtes.2020.72472 Submitted: 14.10.2019 Accepted: 17.04.2020 Online: 27.10.2020

Copyright 2020 Turkish Association of Trauma and Emergency Surgery
} 
This study aimed to make an evidence-based presentation and prepare a national guideline for the management of severe acute pancreatitis by evaluating the feedback provided by general surgical specialists who attended the National Surgical Congress.

\section{MATERIALS AND METHODS}

This study included a survey of surgeon preferences in the management of acute pancreatitis. All the respondents, who were specialists in general surgery, interviewed during the National Surgery Congress, were asked to answer a questionnaire, which was designed after a thorough evaluation of the international guidelines (Appendix). Only \% I00 answered questionnaires were used for the survey. Critical topics were identified according to the American College of Gastroenterology (ACG) guidelines and the recommendations were accepted as correct. SPSS 22.0 (IBM Corp., Armonk, NY, USA) was used for statistical analysis. The distribution of the answers was expressed as a percentage.

Health services in Turkey consist of non-profit government hospitals, training and research hospitals, university hospitals, and private hospitals. Since there is no emergency or trauma subspecialization in the general surgery curriculum, general surgery specialists handle the management of acute biliary pancreatitis in Turkey. Therefore, this survey was conducted only with general surgery specialists. According to a recent study conducted by Yastı et al.,"] in Turkey, 48.4\% of specialists in general surgery worked at hospitals affiliated with the Ministry of Health and the remaining specialists worked in private hospitals and university hospitals. Based on this fact, post-hoc power analysis of the current survey study revealed a value of $36.8 \%$ when alpha was accepted at 0.05 using MedCalc v19.I statistical software (MedCalc Software Ltd, Ostend, Belgium).

\section{RESULTS}

In this study, 94 participants were included. Eleven (12\%) patients were female and $83(88 \%)$ were male. All the participants were general surgery specialists. The participants were divided into five groups according to the institutions they worked at, and 84 (90\%) specialists were employed at non-profit hospitals. As summarized in Table I, 5 I (54\%) experts had more than 10 years of experience. Regardless of the type and severity of pancreatitis, 66 (70\%) participants believed that hospitalization was required for the patients. All participants gave priority to amylase and CRP values during clinical follow-up; however, they also considered other parameters, such as leukocyte, lipase, AST, ALT, and bilirubin values. In addition to imaging methods, such as ultrasound and computed tomography (CT), the majority of the participants preferred magnetic resonance cholangiopancreatography (MRCP) alone without the upper abdominal sections. Seventy-four (78\%) participants stated that MRCP must be performed only when the bilirubin levels are elevated. In addition, 54 (57\%) institutions performed endoscopic retrograde cholangiopancreatography (ERCP). For the management of biliary pancreatitis, 78 (82\%) participants stated that they definitely evaluated the Ranson and Atlanta criteria. The correct response rate in two critical topics, enteral nutrition and

Table I. Professional experience in general surgery (PEG)

\begin{tabular}{lcccccc}
\hline & PEG-I & PEG-2 & PEG-3 & PEG-4 & PEG-5 & PEG-6 \\
\hline Number of participants & 15 & 28 & 22 & 14 & 7 & 8 \\
Percentage & $15.9 \%$ & $29.6 \%$ & $23.9 \%$ & $14.6 \%$ & $7.4 \%$ & $8.6 \%$ \\
\hline
\end{tabular}

*PEG-I: <5 years; PEG-2: 6-10 years; PEG-3: II-15 years; PEG-4: 16-20 years; PEG-5: 2I-25 years; PEG-6: >25 years.

All participants in this study are general surgical assistants and specialists at the National Surgery Congress.

Table 2. Correct answers rate among participants

\begin{tabular}{lccccc}
\hline $\begin{array}{l}\text { Total participant } \\
(\mathbf{n}=94)\end{array}$ & $\begin{array}{c}\text { Initial management } \\
\text { of AP }\end{array}$ & $\begin{array}{c}\text { The role of } \\
\text { ERCP in AP }\end{array}$ & $\begin{array}{c}\text { The role of } \\
\text { antibiotics in AP }\end{array}$ & $\begin{array}{c}\text { Nutrition } \\
\text { in AP }\end{array}$ & $\begin{array}{c}\text { The role of } \\
\text { surgery in AP }\end{array}$ \\
\hline PEG-1 & $40 \%$ & $40 \%$ & $46.6 \%$ & $60 \%$ & $60 \%$ \\
PEG-2 & $67.8 \%$ & $32.1 \%$ & $60.7 \%$ & $57.1 \%$ & $35.7 \%$ \\
PEG-3 & $86.3 \%$ & $45.4 \%$ & $54.5 \%$ & $54.5 \%$ & $50 \%$ \\
PEG-4 & $87.1 \%$ & $42.8 \%$ & $42.8 \%$ & $28.5 \%$ & $42.8 \%$ \\
PEG-5 & $90.7 \%$ & $28.5 \%$ & $57.1 \%$ & $37.5 \%$ & $42.8 \%$ \\
PEG-6 & $100 \%$ & $37.5 \%$ & $25 \%$ & $50 \%$ \\
\hline
\end{tabular}

AP: Acute pancreatitis; ERCP: Endoscopic retrograde cholangiopancreatography; PEG-I: Professional experience <5 years; PEG-2: Professional experience 6-I0 years; PEG3: Professional experience II-15 years; PEG-4: Professional experience 16-20 years; PEG-5: Professional experience 2I-25 years; PEG-6: Professional experience >25 years. 


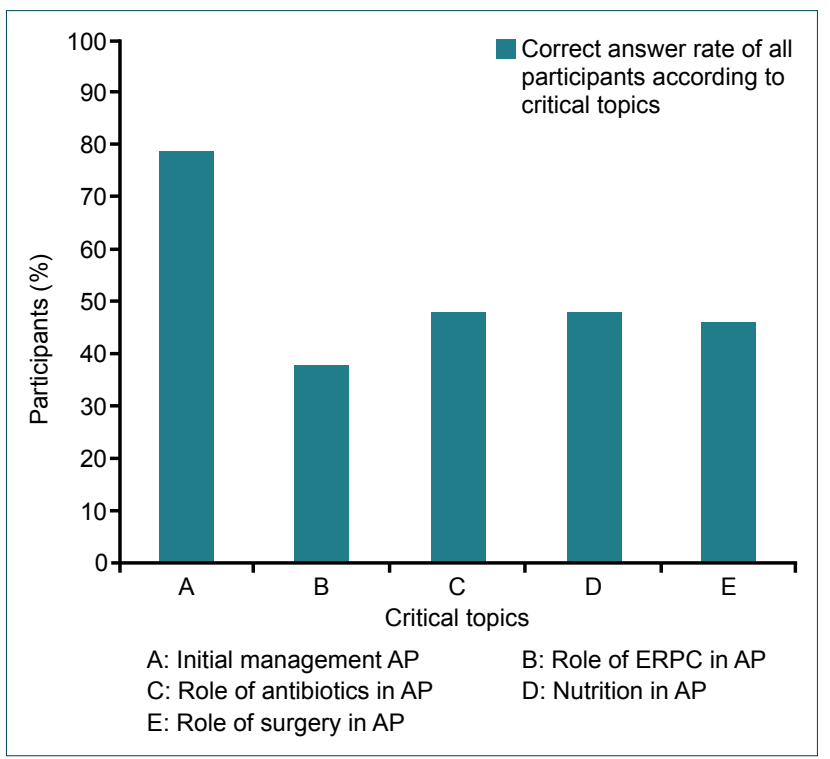

Figure 1. The correct response rate given by the participants to the critical topics and responses determined according to the American Collage of Gastroenterology (ACG) published in 2013.

the role of antibiotics, in the guideline was 48 (51\%) and 36 (39\%), respectively. In patients with mild to moderate pancreatitis, 4 I (44\%) participants supported early cholecystectomy, and $19(20 \%)$ participants did not agree with this approach. In addition, late cholecystectomy was preferred by 4 I (43\%) participants for patients with severe pancreatitis. Thirty-six (38\%) participants suggested cholecystectomy in patients with biliary pancreatitis who had undergone sphincterotomy during ERCP. According to the experience of the participants, the rates of correct answers for critical topics are shown in Table 2, and the overall success percentage in the questions is shown in Figure I.

\section{DISCUSSION}

Acute pancreatitis is an inflammatory condition of the pancreas with a mild form that can be rapidly improved via fluid resuscitation, pain and nausea management, and early oral nutrition in the majority of patients. Often, the cause of pancreatitis is gallstones or excessive alcohol use and usually requires hospitalization. Acute pancreatitis may be more severe in 20-30 percent of the patients and may be fatal in 15 percent of the patients. ${ }^{[8]}$ Gastroenterologists and surgeons most often use the Atlanta classification revised in 2013 and international consensus definitions for acute pancreatitis. According to this classification, we usually encounter a mild form of the disease, which recovers in the first week without organ failure and local or systemic complications. However, patients with a moderate form of the disease exhibit temporary (less than $48 \mathrm{~h}$ ) organ failure, local complications, or exacerbation of the co-morbid disease. Patients suffering from a severe form of the disease exhibit persistent organ failure (over 48 h). Worsening organ dysfunction in severe acute pancreatitis is associated with necrosis of the pancreas and associated infection. ${ }^{[2]}$ In a meta-analysis of 6970 patients, the mortality rate was $35.2 \%$ in patients with infected necrosis and organ failure, while the mortality rate was $1.4 \%$ if they had undergone infected necrosis without organ failure or sterile necrosis and organ failure. ${ }^{\left[{ }^{9]}\right.}$ Currently, early enteral nutrition in severe acute biliary pancreatitis, evaluation of prophylactic antibiotics, avoidance of surgery in patients with sterile necrosis, a more conservative approach to infected necrosis, various trends in endoscopic or surgical treatment, and management of the disease have changed our clinical practice. ${ }^{[10]}$

As with any disease, evidence-based therapy is necessary to provide high-quality care with better outcomes in acute pancreatitis patients. Several studies have been conducted by surgeons and clinicians to demonstrate that acute pancreatitis does not meet management standards. ${ }^{[1,12]}$ Mortality rates in acute pancreatitis are influenced by many factors, such as etiology, age, comorbid diseases, degree of pancreatic necrosis, and multiple organ failure. ${ }^{[13,14]}$

In practice, early aggressive fluid replacement and early enteral nutrition are recommended for the management of acute pancreatitis. These guidelines also agreed that invasive procedures, such as endoscopic sphincterotomy and antibiotics in selected patients, are beneficial in acute cholangitis. ${ }^{[15]} \mathrm{A}$ previous study reported improvements concerning complications, duration of hospital stay, and morbidity and mortality rates of patients followed and treated according to the standard guidelines or protocols. ${ }^{[16]}$

There are many obstacles, including the lack of knowledge of surgeons and the lack of clinical decision support tools, which may lead to non-compliance or poor compliance with standard guidelines. Despite all the barriers, training of major physicians and better definition of clinical decision support tools have resulted in tighter adherence to the guidelines and better clinical outcomes during the management of acute pancreatitis. ${ }^{[15,16]}$ A similar survey study, which addressed the lack of knowledge of physicians, was conducted with internal medicine and surgical physicians at Abington Jefferson Health; however, the proportion of surgical physicians was relatively low. ${ }^{[17]}$ We should note that similar results in our study indicated a lack of knowledge among the physicians.

Another survey, published in 2012, was conducted with 240 (45\%) participants from 49 countries. In this study, classifying the severity of acute pancreatitis based on the Atlanta approach was considered to be insufficient by the majority of the participants. ${ }^{[18]}$ Hence, it is unclear how many international guides could be adequately used at the national level.

A survey involving $54 \%$ of the Union of Surgeons of Great Britain and Ireland showed that only a small number of surgeons believed in the benefits of early laparoscopic cholecystectomy in patients with acute biliary pancreatitis. ${ }^{[9]}$ Similarly, our results also suggested that early laparoscopic cholecys- 
tectomy is not preferred, but a forward referral is preferred by the surgeons.

Surgeons, clinicians, or physicians performing initial evaluation need further training on the guidelines for the management of acute pancreatitis. This can only be achieved by organizing training courses and changing the established rules of the hospitals. To achieve better medical outcomes, it is necessary to establish a national-level admission order form, based on the standard guidelines for the early management of acute pancreatitis, as defined in the electronic medical records of hospitals and agreed by the surgeons. In addition, examinations, such as ERCP and MRI, can be expanded, and operating room and intensive care conditions can be improved by the Ministry of Health. For the management of acute pancreatitis, it is critical and necessary that the surgeons and clinicians who evaluate the patients in the emergency department have a good knowledge of the current guidelines. ${ }^{[2,3,6,20-22]}$

The limitation of this study was that it was a survey conducted at a single national surgical congress with surgeons who have gained experience in the field of gastroenterology. It constituted only $48 \%$ of the surgeons attending the congress and was relatively low. It did not include other specialist clinicians and general practitioners who have evaluated the cases of acute pancreatitis.

\section{Conclusions}

In general, the majority of our surgeons who answered the survey questions regarding the management of acute pancreatitis agreed on the answers to the questions. This survey showed that the surgeons did not have adequate information about the initial assessment, risk classification, fluid resuscitation, antibiotics, enteral nutrition, and the role of ERCP in acute pancreatitis management. That other clinicians and emergency department practitioners who were not yet specialized in this study were not included in the survey study prevented the comparisons between physicians. However, the findings of this survey could help provide guidelines for the management of acute pancreatitis.

Peer-review: Internally peer-reviewed.

Authorship Contributions: Concept: E.S., I.Ş.S.; Design: E.S., I.Ş.S.; Supervision: E.S., İ.Ş.S.; Resource: E.S., İ.Ş.S., M.C.K., Y.K., T.A., T.S., Y.S.; Materials: E.S., I.Ş.S., M.D., B.Z.Y., R.G., C.Ö., O.S., A.Ö. C.B.; Data: E.S., I.Ş.S., M.D., B.Z.Y., R.G., C.Ö., O.S., A.Ö., C.B.; Analysis: E.S., I.Ş.S.; Literature search: E.S., Y.K.; Writing: E.S., Y.K.; Critical revision: E.S., I.Ş.S., Y.K., M.U.K.

Conflict of Interest: None declared.

Financial Disclosure: The authors declared that this study has received no financial support.

\section{REFERENCES}

1. Talley NJ, Locke GR, Moayyedi P, West J, Ford AC. GI Epidemiology:
Diseases and Clinical Methodology. 2nd Edition. New Jersey, USA: John Wiley \& Sons; 2014. [CrossRef]

2. Tenner S, Baillie J, DeWitt J, Vege SS; American College of Gastroenterology. American College of Gastroenterology guideline: management of acute pancreatitis. Am J Gastroenterol 2013;108:1400-16. [CrossRef]

3. Working Party of the British Society of Gastroenterology; Association of Surgeons of Great Britain and Ireland; Pancreatic Society of Great Britain and Ireland; Association of Upper GI Surgeons of Great Britain and Ireland. UK guidelines for the management of acute pancreatitis. Gut 2005;54:iii1-9. [CrossRef]

4. DiMagno MJ. Clinical update on fluid therapy and nutritional support in acute pancreatitis. Pancreatology 2015;15:583-8. [CrossRef]

5. Loveday BP, Srinivasa S, Vather R, Mittal A, Petrov MS, Phillips AR, et al. High Quantity and Variable Quality of Guidelines for Acute Pancreatitis: A Systematic Review. Am J Gastroenterol 2010;105:1466-76.

6. Greenberg JA, Hsu J, Bawazeer M, Marshall J, Friedrich JO, Nathens A, et al. Clinical practice guideline: management of acute pancreatitis. Can J Surg 2016;59:128-40. [CrossRef]

7. Yastı $A C ̧, U$ çar AD, Kendirci M. General surgery specialism in Turkey: work power currently, continuity at quality and quantity. Turk J Surg 2019;36:82-95. [CrossRef]

8. van Santvoort HC, Bakker OJ, Bollen TL, Besselink MG, Ahmed Ali U, Schrijver AM, et al. A conservative and minimally invasive approach to necrotizing pancreatitis improves outcome. Gastroenterology 2011;141:1254-63. [CrossRef]

9. Werge M, Novovic S, Schmidt PN, Gluud LL. Infection increases mortality in necrotizing pancreatitis: A systematic review and meta-analysis. Pancreatology 2016;16:698-707. [CrossRef]

10. Leppäniemi A, Tolonen M, Tarasconi A, Segovia-Lohse H, Gamberini E, Kirkpatrick AW, et al. 2019 WSES guidelines for the management of severe acute pancreatitis. World J Emerg Surg 2019;14:27. [CrossRef]

11. Vlada AC, Schmit B, Perry A, Trevino JG, Behrns KE, Hughes SJ. Failure to follow evidence-based best practice guidelines in the treatment of severe acute pancreatitis. HPB (Oxford) 2013;15:822-7. [CrossRef]

12. Sun E, Tharakan M, Kapoor S, Chakravarty R, Salhab A, Buscaglia JM, et al. Poor compliance with ACG guidelines for nutrition and antibiotics in the management of acute pancreatitis: a North American survey of gastrointestinal specialists and primary care physicians. JOP 2013;14:221-7.

13. Pitchumoni CS, Patel NM, Shah P. Factors influencing mortality in acute pancreatitis: can we alter them?. J Clin Gastroenterol 2005;39:798-814. [CrossRef]

14. de Beaux AC, Palmer KR, Carter DC. Factors influencing morbidity and mortality in acute pancreatitis; an analysis of 279 cases. Gut 1995;37:121-6. [CrossRef]

15. Rebours V, Lévy P, Bretagne JF, Bommelaer G, Hammel P, Ruszniewski P. Do guidelines influence medical practice? Changes in management of acute pancreatitis 7 years after the publication of the French guidelines. Eur J Gastroenterol Hepatol 2012;24:143-8. [CrossRef]

16. Pupelis G, Austrums E, Snippe K. Importance of a clinical protocol in the treatment of severe acute pancreatitis. [Article in German] Zentralbl Chir 2002;127:975-81. [CrossRef]

17. Mehmood A, Ullah W, Chan V, Ringold D. The Assessment of Knowledge and Early Management of Acute Pancreatitis Among Residents. Cureus 2019;11:e4389. [CrossRef]

18. Petrov MS, Vege SS, Windsor JA. Global survey of controversies in classifying the severity of acute pancreatitis. Eur J Gastroenterol Hepatol 2012;24:715-21. [CrossRef]

19. Senapati PS, Bhattarcharya D, Harinath G, Ammori BJ. A survey of the timing and approach to the surgical management of cholelithiasis in pa- 
tients with acute biliary pancreatitis and acute cholecystitis in the UK. Ann R Coll Surg Engl 2003;85:306-12. [CrossRef]

20. Yokoe M, Takada T, Mayumi T, Yoshida M, Isaji S, Wada K, et al. Japanese guidelines for the management of acute pancreatitis: Japanese Guidelines 2015. J Hepatobiliary Pancreat Sci 2015;22:405-32. [CrossRef]

21. Isaji S, Takada T, Mayumi T, Yoshida M, Wada K, Yokoe M, et al. Re- vised Japanese guidelines for the management of acute pancreatitis 2015: revised concepts and updated points. J Hepatobiliary Pancreat Sci 2015;22:433-45. [CrossRef]

22. Liao WC, Tu TC, Lee KC, Tseng JH, Chen MJ, Sun CK, et al. Taiwanese consensus recommendations for acute pancreatitis. J Formos Med Assoc 2020;119:1343-52. [CrossRef]

\section{ORIJINAL ÇALIŞMA - ÖZET}

\section{Akut biliyer pankreatit tanısında, izleminde ve tedavisinde farklı yaklaşımlar: Tutum anketi sonuçları \\ Dr. Erkan Somuncu, ${ }^{1}$ Dr. İnanç Şamil Sarıcı, ${ }^{1}$ Dr. Mehmet Celal Kızılkaya, ${ }^{1}$ Dr. Yasin Kara, ${ }^{1}$ Dr. Talha Sarıgöz, ${ }^{2}$ Dr. Yusuf Sevim, ${ }^{2}$ Dr. Tansu Altıntaş, ${ }^{1}$ Dr. Musa Diri, ${ }^{1}$ Dr. Betül Zeynep Yıldız, ${ }^{1}$ Dr. Rıdvan Gökay, ${ }^{1}$ Dr. Cenk Özkan,, ${ }^{1}$ Dr. Osman Sıbıç, ${ }^{3}$ Dr. Adem Özcan, ${ }^{1}$ Dr. Ceren Basaran, ${ }^{1}$ Dr. Mustafa Uygar Kalaycı ${ }^{1}$}

'Sağlık Bilimleri Üniversitesi İstanbul Kanuni Sultan Süleyman Eğitim ve Araştırma Hastanesi, Genel Cerrahi Anabilim Dalı, İstanbul ${ }^{2}$ Kayseri Şehir Hastanesi, Genel Cerrahi Kliniği, Kayseri

AMAÇ: Akut biliyer pankreatit, acil cerrahi hastalıklarda genel cerrahlar arasında en sık karşılaşılan hastalıklardan biridir. Hekimden hekime değişen bu hastaların tanı ve tedavi yönetimindeki farklılıklar klinik uygulamada sık görülür. Bu farklııkları sunmayı ve sonuçları literatürdeki güncel kılavuzlar ışığında tartışmayı amaçladık.

GEREÇ VE YÖNTEM: Akut biliyer pankreatit tanısında, takibinde ve tedavisinde hekimlerin yaklaşımlarına ilişkin 2 I soru hazırlandı (Ek-A). Anketler, 20. Ulusal Cerrahi Kongresi'nde 94 genel cerrahi uzmanıyla yüz yüze görüşülerek dolduruldu.

BULGULAR: Anketi cevaplayan hekimlerin 38'i (\%40) eğitim ve araştırma hastanesinde, 27'si (\%29) devlet hastanesi'nde, 19'u (\%20) üniversite hastanesinde ve 9'u özel sağlık kuruluşunda çalışmakta idi. Hekimlerin \%85'i 10 yıllık deneyime sahip genel cerrahi uzmanlarıydı. Cerrahların \%53'ü (50) her ay beşten az akut biliyer pankreatit vakası gördüğünü ve \%35'i (34) takip için günlük olarak amilaz değeri istediklerini belirtti. Ultrasonografi ve bilgisayarlı tomografi en sık kullanılan görüntüleme yöntemleri idi ve yanıt verenlerin \% I 5 'i her hastaya manyetik rezonans kolanjiyopankreatografi yaptığını belirtti. Cerrahların \% 45 'i pankreatit tanısı sırasında antibiyotik başladığını belirtti. Hafif-orta şiddette pankreatitli hastalarda erken dönemde kolesistektomi yapmayan cerrahların oranı \%60 idi. Erken dönemde ameliyatı tercih etmeme nedeni \%40 ile en sık ameliyat zorluğu ve ameliyatı erken dönemde desteklememe fikri idi.

TARTIŞMA: Tutum anketi sonuçlarına göre akut biliyer pankreatit tanısı, takibi ve tedavisinde genel cerrahi uzmanları arasında farklııklar bulunmaktadır. Anahtar sözcükler: Akut biliyer pankreatit; pankreatit için tutum anketi; pankreatitin yönetimi.

Ulus Travma Acil Cerrahi Derg 2020;26(6):932-936 doi: 10.14744/tjtes.2020.72472

Appendix. Approach and attitude in acute biliary pancreatitis

I. How many years have you been working as a surgical specialist? a) $<5$ years b) 5-10 years c) 10-15 years d) 15-20 years

e) $20-25$ years $f$ ) $>25$ years

2. How many days in a month can you perform surgery in your hospital?

a) I day b) 2 days c) 3 days d) 4 days e) $\geq 5$ days

3. Do you have an intensive care unit in the hospital? a) Yes b) No

4. How many biliary pancreatitis cases you encounter in a month in the hospital? a) $<5$ b) $5-10$ c) $\geq 10$

5. What are the most important biochemical parameters in the management of acute pancreatitis?

a) Leukocyte count b) Amylase c) Lipase d) Liver function tests

e) The level of bilirubin $f$ ) CRP

6. How often do you want to see the amylase value? a) Everyday b) It is enough to look at the diagnosis

7. When do you start antibiotics on the patient in the management of pancreatitis?

a) In any case, I start b) In case of high fever

c) In the presence of complications

d) In the presence of infection on radiological examination

8. When do you start oral nutrition to the patient?

a) I do not stop b) According to the tolerability of oral nutrition

c) According to laboratory values and imaging results

d) I stop oral feeding independently of all factors

9. Which imaging methods do you often prefer?

a) US b) CT c) MR d) MRCP

10. When would you prefer to hospitalize the patient? a) Never b) If the Ranson score is $>3$ c) Always
II. When do you perform MRCP?

a) Always b) According to laboratory values c) Never

12. Can you perform abdominal CT according to Ranson criteria? a) Never b) If the Ranson score is $>3$ c) Always

13. When do you perform cholecystectomy in a case of mild-moderate biliary pancreatitis?

a) Normal laboratory values during hospitalization b) Within 2 weeks

c) Within 2-4 weeks d) Within 4-8 weeks e) After 8 weeks

14. Why do not you prefer cholecystectomy early?

a) Busy work b) Time-consuming documentation

c) No room in hospital d) Surgery is technically difficult in this period

e) I do not recommend early cholecystectomy

15. Can you consider Atlanta criteria before cholecystectomy?

a) Always b) Sometimes c) Never

16. When do you perform a cholecystectomy in a patient with severe biliary pancreatitis?

a) When laboratory values are normalized

b) Observing complications within 2 weeks

c) Within 4-8 weeks d) After 8 weeks

17. Is ERCP performed in your hospital? a) Yes b) No

18. When to perform cholecystectomy in patients undergoing sphincterotomy via ERCP?

a) When laboratory values are normalized b) Within 2 weeks

c) Within 2-4 weeks d) Within 4-8 weeks e) After 8 weeks

19. What is the status of your institution?

a) Public hospital b) Training and research hospital

c) University Hospital d) Private health institution e) others 